\title{
Kualitas Dadih dengan Pemberian Daun Singkong sebagai Pakan Suplemen
}

\author{
Curd Quality with Cassava Leaf Feeding as Feed Supplements
}

\author{
E. Roza, M.S. Suardi, E. Nurdin, S.N. Aritonang \\ Fakultas Peternakan Universitas Andalas, \\ Kampus Unand Limau Manis Padang, 25163 \\ e-mail: ell_roz@yahoo.com
}

(Diterima: 2 Juli 2012, Disetujui: 29 Oktober 2012)

\begin{abstract}
The purpose of this study was to determine the effect of the use of cassava leaves as feed supplement on the quality of buffalo curd in cattle traditionally reared. This study used 20 female buffaloes at second and third lactation Sijunjung district. The method was used a completely randomized design ( $C R D$ ) with 4 treatments and 5 replications. The material was used a feed supplement in the pellets form that consisted of urea (7.5\%), saka (20\%), cassava leaf meal (10\%), bran $(37.5 \%)$, salt $(8 \%)$, cement $(10 \%)$, mineral mixture $(2 \%)$ and water $(5 \%)$. The treatment were supplementation of cassava leaves as much as A : $0 \mathrm{~kg} / \mathrm{head} /$ day , B : $0.5 \mathrm{~kg} / \mathrm{head} / \mathrm{day}, C: 1.0 \mathrm{~kg} /$ head / day and D : $1.5 \mathrm{~kg} /$ head / day. Variables measured were moisture content, protein, and the acidity of the curd. The results showed that feeding supplements significant influence $(P<0.01)$ on milk composition ( moisture $80.93 \%$, protein $7.95 \%$, viscosity 2.68 Cpa and acidity $1.22 \%$ ). It was concluded that the feeding supplements of $1.5 \mathrm{~kg} / \mathrm{head} /$ day (Treatment D) may increase the protein, acidity, viscosity and decrease of whey.
\end{abstract}

Keywords : feed supplements, curd, protein, acidity, viscosity

\section{PENDAHULUAN}

Di Sumatera Barat, populasi ternak kerbau hasil PSPK 2011 tercatat sebanyak 100.310 ekor (Dirjen Peternakan dan Kesehatan Hewan, 2012). Ternak kerbau merupakan ternak lokal yang memiliki peranan penting dalam kehidupan masyarakat. Kontribusinya secara ekonomi bagi peternak cukup signifikan karena kerbau merupakan ternak multiguna, yaitu sebagai ternak kerja, penghasil daging dan susu serta kulitnya dapat dimanfaatkan sebagai bahan baku industri. Produksi susu kerbau lumpur di Sumatera Barat masih rendah, yaitu sekitar 1,50 $\pm 0,53$ liter/hari (Ibrahim, 2008). Hal ini disebabkan pemeliharaan ternak kerbau di Sumatera Barat umumnya masih sederhana, dengan melepasnya sepanjang hari di padang penggembalaan milik bersama masyarakat setempat dengan hijauan seadanya. Keterbatasan sumber hijauan/rumput lapangan yang berasal dari lingkungan se- tarnya dengan kualitas gizi yang rendah berdampak buruk terhadap produksi.

Alternatif untuk mengatasi hal tersebut adalah dengan memanfaatkan bahan lain yang digunakan sebagai sumber protein seperti daun singkong. Daun singkong atau ubi kayu (Manihot esculenta, Crantz) mempunyai potensi untuk dimanfaatkan sebagai komponen pengganti urea dalam pakan suplemen ini. Daun singkong yang telah dikeringkan (hay) merupakan sumber protein, dan dapat dimanfaatkan sebagai suplemen pada nutrisi ruminansia terutama pada sapi perah, sapi pedaging dan kerbau (Wanapat, 1993; Wanapat et al., 2000a; 2000b; Khang et al., 2005). Adapun pemberiannya dapat secara langsung sebagai suplemen pakan dan sebagai sumber protein dalam konsentrat (Wanapat et al., 2000; Hong et al., 2003) atau sebagai komponen bahan dalam pakan blok yang memiliki kualitas tinggi (Wanapat dan Khampa, 2006).

Di beberapa tempat di Sumatera Barat seperti di Kabupaten Agam, Sijunjung dan So- 
lok, susu kerbau dimanfaatkan untuk diolah menjadi dadih yaitu susu yang difermentasi dalam tabung bambu. Dadih dikonsumsi sebagai lauk-pauk dan makanan selingan yang manfaatnya menyehatkan Produk ini sangat digemari masyarakat daerah setempat sebagai pangan fungsional. Usaha pengolahan dadih memberikan kontribusi terhadap penghasilan keluarga peternak di daerah. Namun produksinya tidak dapat memenuhi kebutuhan konsumen karena terbatasnya produksi maupun kualitas susu yang dihasilkan, padahal produksi dan kualitas susu berpengaruh terhadap kualitas dadih yang dihasilkan. Mengacu pada kandungan protein yang cukup tinggi pada daun singkong dan ketersediaan tanaman tersebut cukup banyak serta mudah diperoleh di pedesaan, maka potensi penggunaannya dalam pakan suplemen sebagai sumber nitrogen masih cukup tinggi.

Berdasarkan hal di atas, dilakukan penelitian untuk mengetahui pengaruh penggunaan daun singkong dalam pakan suplemen terhadap kualitas dadih pada ternak kerbau yang diperah dipelihara secara tradisional. Hasil penelitian ini diharapkan dapat memberikan informasi teknis tentang pemanfaatan daun singkong sebagai pakan suplemen bentuk pellet dalam meningkatkan kualitas dadih dan memberikan sumbangan untuk pengembangan ternak kerbau penghasil dadih di Sumatera Barat.

\section{METODE}

Penelitian ini menggunakan 20 ekor kerbau betina laktasi 2 dan 3 dengan kisaran umur 4-5 tahun di Kabupaten Sijunjung. Ternak kerbau diberi pakan suplemen selama tiga (3) bulan, diberikan dua kali sehari yaitu pagi (sebelum dilepas ke padang penggembalaan) dan sore hari setelah masuk kandang, hijauan diperoleh di padang penggembalaan. Pakan suplemen dibuat dalam bentuk pellet, yang terdiri dari urea $(7,5 \%)$, saka $(20 \%)$, daun singkong $(10 \%)$, dedak $(37,5 \%)$, garam $(8 \%)$, semen (10\%), mineral mix (2\%) dan air (5\%). Proses pengolahan pellet dilakukan dengan memanaskan saka dan urea dengan air hingga mencair kemudian di aduk dengan campuran bahan-bahan lain hingga merata. Campuran tersebut kemudian dicetak dan dikeringkan dibawah sinar matahari selama 2 - 3 hari.

Rancangan yang digunakan adalah Rancangan Acak Lengkap (RAL) terdiri dari 4 perlakuan dan 5 ulangan. Perlakuan yang diberikan adalah pakan suplemen daun singkong: A. $0 \mathrm{~kg} / \mathrm{ekor} / \mathrm{hari}$; B. 0,5 kg/ekor/hari; C. $1 \mathrm{~kg} / \mathrm{ekor} / \mathrm{hari}$ dan D.1,5 kg/ekor/hari. Analisis data dilakukan dengan menggunakan Analisis of Varian (ANOVA), untuk mengetahui perbedaan antar perlakuan dihitung dengan Duncan's Multiple Range Test (Steel dan Torrie, 1995). Peubah yang diamati adalah kualitas dadih : kadar air (metode pengeringan) kadar protein (metode Kjeldahl), keasaman dan viskositas dadih.

\section{HASIL DAN PEMBAHASAN}

\section{Pengaruh Pemberian Pakan Suplemen Terhadap Kualitas Dadih}

Rataan kualitas dadih pada ternak kerbau laktasi yang diberi pakan suplemen daun singkong dapat dilihat pada Tabel 1.

\section{Kadar Air Dadih.}

Dari Tabel 1 terlihat rataan kadar air dadih tertinggi terdapat pada perlakuan A yaitu $82,0 \%$ dan terendah pada perlakuan D yaitu $80,93 \%$. Hasil analisis keragaman terlihat bahwa pemberian pakan suplemen daun singkong memberikan pengaruh yang sangat nyata $(\mathrm{P}<0,01)$ terhadap kadar air dadih. Hasil uji DMRT menunjukkan bahwa kadar air dadih pada perlakuan D sangat nyata paling rendah dibandingkan perlakuan lainnya, sedangkan perlakuan A, B dan C tidak berbeda nyata. Ini berarti bahwa pemberian pakan suplemen daun singkong sangat nyata menurunkan kadar air dadih.

Menurunnya kadar air dadih akibat pemberian pakan suplemen daun singkong disebabkan pakan suplemen tersebut mengandung protein dan karbohidrat yang dapat meningkatkan kualitas susu terutama protein susu. Dalam proses pembuatan dadih Bakteri Asam Laktat (BAL) akan merombak laktosa menjadi asam laktat sehingga asam laktat yang dihasilkan meningkat. Meningkatnya asam laktat dalam dadih akan meningkatkan 
Tabel 1. Rataan Kadar Air, Protein, Keasaman dan Viskositas Dadih pada Ternak Kerbau Laktasi yang Diberi Pakan Suplemen

\begin{tabular}{lcccc}
\hline \multirow{2}{*}{\multicolumn{1}{c}{ Peubah }} & \multicolumn{4}{c}{ Perlakuan } \\
\cline { 2 - 5 } & $\mathrm{A}$ & $\mathrm{B}$ & $\mathrm{C}$ & $\mathrm{D}$ \\
\hline Kadar Air (\%) & $82,00 \pm 0,55^{\mathrm{Aa}}$ & $81,86 \pm 0,59^{\mathrm{Aa}}$ & $81,67 \pm 0,18^{\mathrm{a}}$ & $80,93 \pm 0,38^{\mathrm{Bb}}$ \\
Kadar Protein (\%) & $6,59 \pm 0,28^{\mathrm{Bb}}$ & $7,30 \pm 0,38^{\mathrm{Ba}}$ & $7,70 \pm 0,47^{\mathrm{a}}$ & $7,95 \pm 0,68^{\mathrm{Aa}}$ \\
Keasaman (\%) $_{\text {Viskositas (Cpa) }}$ & $1,07 \pm 0,49^{\mathrm{Cc}}$ & $1,16 \pm 0,03^{\mathrm{Bb}}$ & $1,20 \pm 0,02^{\mathrm{Ba}}$ & $1,22 \pm 0,11^{\mathrm{Aa}}$ \\
\hline
\end{tabular}

Keterangan :Superskrip yang diikuti huruf kecil yang berbeda pada baris yang sama berbeda nyata $(\mathrm{P}<0,05)$ dan dengan huruf besar berbeda sangat nyata $(\mathrm{P}<0.01)$.

total padatan, yang diikuti oleh penurunan kandungan air dadih sehingga penggumpalan protein susu menjadi curd juga meningkat.

Paling rendahnya kadar air dadih pada perlakuan $\mathrm{D}$, disebabkan pemberian daun singkong sampai $1,5 \mathrm{~kg}$ dapat meningkatkan pertumbuhan dan aktivitas mikroorganisme dalam merombak laktosa menjadi asam laktat sehingga asam laktat yang dihasilkan pun lebih tinggi. Semakin tingginya asam laktat yang dihasilkan akan meningkatkan koagulasi protein dalam dadih, sehingga kandungan air dadih menjadi lebih rendah yang diikuti oleh meningkatnya total solid dadih. Seperti yang dikemukan oleh Rahman et al.(1992) bahwa menurun atau meningkatnya kadar air akan berpengaruh terhadap total solid pada susu fermentasi akibat terjadinya suasana asam dan koagulasi protein.

\section{Protein Dadih.}

Hasil analisis keragaman terlihat bahwa pemberian pakan suplemen daun singkong memberikan pengaruh yang sangat nyata $(\mathrm{P}<0,01)$ terhadap kadar protein dadih. Hasil uji DMRT, kadar protein perlakuan D nyata paling tinggi dibandingkan perlakuan lainnya, tetapi berbeda tidak nyata dengan kadar protein dadih pada perlakuan B dan C. Ini berarti bahwa pemberian pakan suplemen nyata meningkatkan kadar protein dadih.

Meningkatnya kadar protein dadih seiring dengan meningkatnya pemberian pakan suplemen daun singkong karena daun singkong merupakan sumber protein (Jalaludin, 1994) dan sumber asam amino rantai bercabang, yang merupakan sumber kerangka karbon yang dibutuhkan untuk menstimulir per- tumbuhan bakteri selulolitik. Bakteri selulolitik sangat responsif terhadap penambahan kerangka karbon bercabang (Nurhaita dkk, 2010) sehingga penambahan konsentrat pakan suplemen yang semakin meningkat (perlakuan D), kadar protein dalam susu juga semakin meningkat (Tabel 1). Hasil penelitian ini lebih tinggi dari dadih asal Kabupaten Agam dan Solok dengan kadar proteinnya 4,08\%, lemak $2,61 \%$ (Sunarlim dan Setiyanto, 2001).

Komponen susu yang paling berperan dalam fermentasi adalah laktosa dan kasein yang digunakan sebagai sumber energi dan karbon yang nantinya akan diubah oleh BAL menjadi asam laktat yang menyebabkan $\mathrm{pH}$ susu turun. BAL mempunyai kemampuan untuk mengkoagulasi protein, sehingga bahan kering dadih meningkat diikuti dengan peningkatan protein. Hal ini sesuai pernyataan Phuc et al. (2008), penggumpalan protein susu terjadi karena BAL yang menghasilkan enzim proteolitik di sekitar dinding sel, membran sitoplasma atau di dalam sel yang menjadikan suasana asam. Kasein menggumpal membentuk koagulan sehingga terbentuk susu semi padat (Helferich dan Westhoff, 1980) Selain itu kadar protein dadih juga berasal dari protein bakteri itu sendiri. Sekitar 7\% dari total protein susu atau produk olahan susu disumbangkan dari bakteri, oleh sebab itu protein dadih meningkat.

\section{Keasaman.}

Hasil analisis keragaman menunjukkan bahwa perlakuan memberikan pengaruh yang sangat nyata $(\mathrm{P}<0,01)$ terhadap total asam laktat (keasaman) dadih. Hal ini menunjukkan bahwa pemberian daun singkong berpengaruh 
sangat nyata terhadap kadar asam laktat dadih yang dihasilkan. Hasil uji DMRT menunjukkan bahwa kadar asam laktat dadih pada perlakuan D (1,22\% TTA) paling tinggi diikuti secara berturut turut oleh perlakuan $\mathrm{C}, \mathrm{B}$ dan $\mathrm{A}$, namun berbeda tidak nyata dengan perlakuan C. Meningkatnya keasaman dadih seiring dengan meningkatnya penambahan daun singkong ke pakan ternak kerbau. Nilai total asam diduga dipengaruhi oleh aktivitas bakteri asam laktat pada dadih selama proses perubahan laktosa susu menjadi asam laktat. Semakin banyak bakteri maka semakin banyak asam laktat yang dihasilkan sehingga total asam menjadi meningkat. Penambahan pakan suplemen daun singkong menyebabkan mutu dan cita rasa dadih yang dihasilkan lebih konsisten dibandingkan dengan dadih tanpa pemberian pakan suplemen daun singkong.

Rendahnya kandungan asam laktat yang dihasilkan pada perlakuan A (1,07\% TTA) disebabkan pada perlakuan A tidak ditambahkan daun singkong sebagai pakan ternak, sehingga nutrisi yang dihasilkan tidak sebanyak yang ditambahkan perlakuan. Akibatnya tidak dapat memacu aktivitas bakteri dadih dalam merombak laktosa menjadi asam laktat, sehingga asam laktat yang dihasilkan tidak banyak, yang artinya keasaman dadih yang dihasilkan pada perlakuan A rendah. Terbentuknya asam disebabkan oleh perombakan laktosa menjadi glukosa dan galaktosa oleh enzim laktase yang dihasilkan oleh mikroba yang selanjutnya diubah menjadi bentuk yang spesifik yaitu asam laktat. Total asam laktat yang dihasilkan berkisar antara 1,07-1,22\% TTA. Hal ini menunjukkan bahwa total asam laktat telah memenuhi SNI 01-2981-1992. Adapun total asam laktat untuk yogurt yang disyaratkan yaitu $0,5 \%-2,0 \%$ TTA.

\section{Viskositas Dadih.}

Hasil analisis keragaman terlihat bahwa pemberian pakan suplemen daun singkong memberikan pengaruh yang sangat nyata $(\mathrm{P}<0,01)$ terhadap viskositas dadih. Hasil uji DMRT menunjukkan viskositas dadih pada perlakuan $D$ nyata paling tinggi diikuti oleh viskositas dadih perlakuan B dan perlakuan A, namun berbeda tidak nyata dengan perlakuan
C. Ini berarti penambahan pakan suplemen daun singkong meningkatkan viskositas dadih.

Meningkatnya viskositas dadih seiring dengan meningkatnya pemberian daun singkong ke pakan ternak kerbau, karena daun singkong mengandung protein yang dapat meningkatkan kualitas susu. Nilai viskositas dadih ditentukan oleh tingginya total padatan susu yang menjadi bahan baku dalam pembuatan dadih. Namun bila dibandingkan dengan viskositas pada perlakuan A tanpa pakan suplemen menghasilkan viskositas yang paling rendah karena kualitas susu yang digunakan dalam proses pembuatan dadih juga rendah terutama kandungan protein susunya.

Di dalam rumen pakan akan mengalami hidrolisa menjadi $\mathrm{NH}_{3}$, VFA, BCFA(asam lemak rantai cabang) dan $\mathrm{CO}_{2}$ (Mc Donald $e t$ al., 1995). $\mathrm{NH}_{3}$ dalam rumen merupakan sumber $\mathrm{N}$ untuk pertumbuhan mikroba. Dengan meningkatnya jumlah mikroorganisme rumen maka kemampuan untuk mencerna zat makanan meningkat. Bakteri selulolitik sangat responsif terhadap penambahan kerangka karbon bercabang (Nurhaita dkk., 2010) sehingga penambahan pakan suplemen yang semakin meningkat (perlakuan D), kadar protein dalam susu juga semakin meningkat. Akibatnya dengan meningkatnya asam laktat akan menggumpalkan protein susu yang menyebabkan dadih menjadi kental sehingga viskositas pada dadih meningkat (Aritonang, 2009).

Peningkatan pemberian daun singkong berdampak terhadap peningkatan aktivitas bakteri dadih untuk merombak laktosa menjadi asam laktat sehingga asam laktat yang dihasilkan meningkat. Seperti tampak pada hasil penelitian ini, pemberian daun singkong paling tinggi $1,5 \mathrm{~kg}$ pada perlakuan D menghasilkan kadar protein paling tinggi, yaitu $7,95 \%$ yang diikuti oleh paling tingginya viskositas pada dadih yaitu 2,68 Cpa. Berbeda tidak nyatanya viskositas dadih pada perlakuan $\mathrm{B}$ dan $\mathrm{C}$ dengan dadih pada perlakuan $\mathrm{D}$ disebabkan pemberian perlakuan sampai $1 \mathrm{~kg}$ pada perlakuan $\mathrm{C}$ belum maksimal dalam reaksinya untuk merubah laktosa menjadi asam laktat. Akibatnya asam laktat yang dihasilkan belum maksimal dalam menggumpalkan protein susu menjadi curd, sehingga penurunan kadar air pun belum maksimal yang diikuti 
oleh belum maksimalnya peningkatan viskositas. Akibatnya dengan pemberian daun singkong dengan jumlah tersebut viskositas dadih yang dihasilkan tidak berbeda.Viskositas berbanding lurus dengan kadar protein dadih dan berbanding terbalik dengan kadar air.

\section{KESIMPULAN}

Berdasarkan hasil penelitian dapat disimpulkan bahwa pemberian pakan suplemen sebanyak 1,5 kg/hari (Perlakuan D) dapat meningkatkan kualitas dadih yaitu protein, keasaman, viskositas dan menurunkan kadar air dadih.

\section{DAFTAR PUSTAKA}

Aritonang,N.S. 2009. Susu dan Teknologi. Swagati Press, Cirebon

Helferich, W. and D. Westhoff. 1980. All About Yogurt. Prentice-Hall, Inc. Inglewood Cliff New York.

Hong, N.T.T., M. Wanapat, C. Wachirapakorn, P. Pakdee and $\mathrm{P}$. Rowlinson. 2003. Effects of timing of initial cutting and subsequent cutting on yields and chemical compositions of cassava hay and its supplementation on lactating dairy cows. Asian-Aust. J. Anim. Sci. 16:1763-1769.

Ibrahim, L. 2008. Produksi susu, reproduksi dan manajemen kerbau perah di Sumatera Barat. Jurnal Peternakan, 5 (1): $1-9$.

Jalaludin. 1994. Uji banding gamal dan angsana sebagai sumber protein, daun kembang sepatu dan minyak kelapa sebagai agen defaunasi dan suplementasi analog hidroksi metionin dan amonium sulfat dalam ransum pertumbuhan sapi perah jantan. Tesis. Fakultas Pascasarjana. Institut Pertanian Bogor, Bogor.

Khang, D. N., H. Wiktorsson and T. R. Preston. 2005. Yield and chemical composition of cassava foliage and tuber yield as influenced by harvesting height and cutting interval. Asian-Aust. J. Anim. Sci. 18:1029-1035.

Mc. Donald, P., R. A. Edwards, J. F. D. Greenhalgh, C. A. Morgan. 1995. Animal Nutrition. Fifth Edition. Longman Scientific \& Technical, New York

Nurhaita, N.Jamarun, L Warly, \& M. Zen. 2010. Sintesis protein mikroba pada domba yang mendapat ransum daun sawit amoniasi yang disuplementasi mineral S,P dan daun ubi kayu. Jurnal Penelitian Universitas Jambi Seri Sains. 12: $107-114$

Phuc, B.H.N., B. Ogle and JE Linberg . 2008. Nutritive value of cassava leaves for monogastric animals. http//WWWN. mekarn.org/procKKJphuc.htm Diakses tanggal 17/12/2008

Rahman, A., S. Fardiaz, W.P. Rahayu, Suliantari dan C.C. Nurwitri. 1992. Teknologi Fermentasi Susu. Pusat Antar Universitas Pangan dan Gizi IPB, Bogor.

Steel, R.G.D., and J.H. Torrie. 1991. Prinsip dan Prosedur Statistik. Suatu Pendekatan Biometrik. Alih bahasa. B. Sumantri. Gramedia. Jakarta.

Sunarlim, R, dan H. Setiyanto. 2001. Penggunaan Berbagai Tingkat Kadar Lemak Susu Kambing dan Susu Sapi terhadap Mutu dan Cita RasaYoghurt. Prosiding. Seminar Nasional Teknologi dan Veteriner. Puslitbangnak, Bogor.

Wanapat, M. 1993. Utilization of cassava leaf (Manihot esculenta, Crantz) in concentrate mixture for swamp buffaloes. In: Ruminant Nutrition Technology Research Project (RUNTERP), Department of Animal Science, Faculty of Agriculture, Khon Kaen University, Thailand. pp. 50-59.

Wanapat, M. 2000a. Rumen manipulation to increase the efficient use of local feed resources and productivity of ruminants in the tropics. Asian-Aust. J. Anim. Sci. 13(Suppl.): 59-67. 
Wanapat, M. 2000b. Role of cassava hay as animal feed in the tropics. In: Proc. Interntional Workshop on Current Research and Development in Use of Cassava as Animal Feed. July 23-24, 2001, Khon Kaen University, Thailand. pp. 13-19.

Wanapat, M. 2003. Manipulation of cassava cultivation and utilization to improve protein to energy biomas for livestock feeding in the tropic. Asian - Aust. J.
Anim. Sci. $16: 463-472$.

Wanapat, M. and S. Khampa. 2006. Effect of cassava hay in high-quality feed block as anthelmintics in steers grazing on ruzi grass. Asian-Aust. J. Anim. Sci. 19: 695-698.

Wanapat, M., C. Promkot and S. Wanapat. 2006. Effect of cassava pellet as a protein source in concentrate on ruminal fementation and digestibility in cattle. Asian-Aust. J. Anim. Sci. 19: 1004-10 
Vol. 14 (3) 